\title{
Why and How Women in Business Can Make Innovations in Light of the Sustainable Development Goals
}

\author{
Paola Demartini 1 \\ Department of Business Study, Roma Tre University, 00154 Roma RM, Italy; paola.demartini@uniroma3.it \\ Received: 20 August 2019; Accepted: 21 August 2019; Published: 25 August 2019 \\ check for \\ updates
}

\section{Introduction}

In 1999, Amartya Sen wrote, “ ... women are increasingly seen, by men as well as women, as active agents of change: the dynamic promoters of social transformations that can alter the lives of both women and men". Moreover, he points out that an increase in women's participation does not only generate results for women in general-a reward on its own merit-but it also provides social benefits as women are a major influence on social change, innovation and the development process (pp. 201-2).

Innovation, indeed, is a matter of change in the life of individuals, organisations and institutions driven not only by scientific and technological advances but also by societal expectations, values and demands (Phills et al. 2008; Cajaiba-Santana 2014; van der Have and Rubalcaba 2016). However, innovation has had a critical and sometimes controversial impact on our society (Godin 2015). What makes the difference is its finalisation and the socio-economic and environmental impact that it produces on the fabric of our society and the physical environment in which we live (Edler and Fagerberg 2017). Innovation as an end and not a means should promote a change that reduces inequalities and promotes well-being as stated in the Sustainable Development Goals (SDGs), which are "a universal call to action to end poverty, protect the planet and ensure that all people enjoy peace and prosperity" (United Nations 2015).

In detail, according to SDG 5: Achieve gender equality and empower all women and girls, women are both the target that policymakers and institutions should pay attention to, through innovative reforms and policies aimed at reducing the inequalities that exist at all levels (see Table 1), and also the means by which to foster innovation and the development of our society (UN Women 2017).

Table 1. Goal 5: Achieve gender equality and empower all women and girls.

5.a Undertake reforms to give women equal rights to economic resources, as well as access to ownership and control over land and other forms of property, financial services, inheritance and natural resources, in accordance with national laws.

5.b Enhance the use of enabling technology, in particular information and communications technology, to promote the empowerment of women.

5.c Adopt and strengthen sound policies and enforceable legislation for the promotion of gender equality and the empowerment of all women and girls at all levels.

In light of these propositions, this editorial develops in two directions.

The first introduces the reader to the more general theme of the relationships between gender conditions and economic development and argues that gender inequality leads to a net loss, both economically and in terms of quality of life (Klasen and Lamanna 2009; Duflo 2012). Not only does gender inequality have economic and social effects on women but also the community as a whole (Klasen 2002; Kabeer and Natali 2013). Accordingly, eliminating gender inequality could lead to a 
radical change within the global economy, not only in terms of economic growth and GDP but also, and above all, in terms of the redistribution of wealth and increased well-being for the entire society (King and Mason 2001; Benería et al. 2015). For this reason, the gender issue has become a point on the agenda of economic policy, both globally and nationally (Cornwall and Rivas 2015).

This premise is important because it is also the underlying pillar of the flourishing of research on both gender inequalities and women in business in recent years (Henry et al. 2016; Paoloni and Demartini 2016).

The second direction introduces the reader to the individual contributions of this book, which mainly concern the most advanced categories of women in business, namely, women entrepreneurs and professionals. Hence, the specific objective is to offer insights to researchers, policymakers and all those interested in reducing gender inequalities and supporting the process of female empowerment and leadership (Cornwall and Rivas 2015).

Finally, the primary purpose of this editorial is to present a picture of both directions and summarise a macro and microeconomic perspective of why and how women in business can make innovations in light of the SDGs.

\section{Gender Inequalities and Economic Development: A Macro Perspective}

In a nutshell, gender inequalities, i.e., the result of social organisation and cultural tradition, take the form of fewer opportunities for women to access and use tangible and intangible resources than men, which limits women's chances of gaining more power both in production and consumption of wealth.

Gender differences are also reflected in the different spending and consumption patterns within the family, with women more strongly promoting investments in children's human capital (Roushdy 2004). The control of women regarding income and wealth is important as a tool for the well-being of children. In fact, the greater control of women concerning income increases spending on assets that also benefit the rest of the family (Schady and Rosero 2008; Rubalcava et al. 2009). For example, it is noted that the share of land owned by women is positively associated with higher spending on food among rural families; that is, if mothers have more land ownership, fewer children are severely underweight (Allendorf 2007).

Advancing gender equality is critical to all areas of a healthy society, from reducing poverty to promoting health, education, protection and the well-being of children and future generations (Abu-Ghaida and Klasen 2004).

Speaking specifically of women in business, we focus on the role that women can have, as workers or as entrepreneurs in a business. Concretely, inequalities can manifest themselves at various stages of a woman's life, especially before entering the workplace, through educational and experiential paths differentiated by gender that limit/influence the acquisition of knowledge, skills and competences by women. The effect of these inequalities translates into greater difficulty for women to establish companies in the most innovative and profitable sectors (BarNir 2012) and enter into the work world in roles with greater prospects (Beede et al. 2011). Once they enter the labour market, with equal responsibilities, women are on average less remunerated than men (Bobbitt-Zeher 2007) and have more difficulty in making a career, a phenomenon well known in the literature for which the term "glass ceiling" has been coined (Cotter et al. 2001; Broadbridge and Weyer 2007). Even for women entrepreneurs, the greater difficulty in accessing, accumulating and using human capital as well as financial resources can limit the success of the company and has fuelled the debate in the literature on "the gender underperformance hypothesis" (Fairlie and Robb 2009). However, beyond ethical reasons, there is an economic rationale for which women must be able to express their potential in the business world. Indeed, the full participation of women in labour forces would add percentage points to most national growth rates-double digits in many cases (https://www.un.org). In general, women's and girls' empowerment is essential to promote social development (United Nations 2018; Duflo 2012). 
In this context, development can also be read as economic and human development. Economic development, commonly captured by per capita GDP, is included in the ISU (Human Development Index), a synthetic measure of human development. In fact, this index measures the average results of a country in the three fundamental dimensions of human development: a long and healthy life, access to knowledge and a decent standard of living (WorldBank 2001).

In the following, we refer to two models that explain and empirically test the impact of gender conditions on economics. What differentiates these models the most is the indices used as a representation of gender conditions:

- The Gender Inequality Index (GII), created by the Human Development Relations Office of the United Nations Development Program (HDRO 2018);

- The gender discrimination index within social institutions (Social Institution and Gender Index, SIGI), created by the OECD Development Centre (2014).

Commonly, these two models lead to identical results, confirming the hypothesis that gender inequality causes damage to the community in terms of lack of development (Ferrant 2011; Ferrant and Kolev 2016).

For the model that uses GII, gender inequality refers to disparity between individuals due to gender. This multidimensional concept contains various aspects that can vary from one country to another depending on the level of development, as well as the social and cultural characteristics and, finally, the institutions. For economic reasons, gender inequality is important because it creates a distortion analogous to a distorted tax. In fact, men less gifted and skilled than women may have better access to education, political, social and economic resources, labour markets and, as a result, economic opportunities. Thus productivity, capital accumulation and technological progress are negatively affected by all the forms in which gender inequality appears (Ferrant 2011, pp. 22-25).

For the model that uses SIGI, discriminatory social institutions are implemented through formal and informal laws, attitudes and practices that limit women's and girls' access to opportunities in terms of rights, justice and empowerment. These are captured in a multifaceted approach from the SIGI variables that combine qualitative and quantitative data, taking into consideration both de jure and de facto discrimination of social institutions. The results show that gender discrimination in social institutions prevents economic development beyond its effects on gender inequality, reducing countries' income levels. This effect is stronger for low-income countries and appears to work by reducing total factor productivity and reducing the level of education and labour participation among women. Furthermore, the analyses show that the loss of income associated with current levels of discrimination could be substantial, estimated at up to $\$ 12$ trillion, $16 \%$ of current global revenues (Ferrant and Kolev 2016, p. 28). At the same time, the authors estimate that a gradual dismantling of gender discrimination in social institutions could bring about significant economic benefits, leading to an annual increase in the global income growth rate from 0.03 to 0.6 per cent points by 2030 (ib: 30).

In summary, both models demonstrate that among the reasons for which local and international policies must be oriented decisively to the abatement of gender inequality, there is also the economic loss and the lack of development caused by it.

The limitations of these empirical analyses must also be remembered. Gender inequality is a social construct and society is a complex environment, in which it is difficult to circumscribe and isolate elements. So, although having an index for gender inequality is very useful and indispensable for quantitative analyses, this indicator is not entirely exhaustive in describing the phenomenon.

However, the empirical evidence that there is a positive relationship between the reduction of gender inequalities and economic development explains why the topic is on policymakers' agenda. But an agenda is not sufficient to put forward results; therefore, it must be translated into targeted and effective actions.

For this reason, in addition to macro-economic analyses, it is essential to develop research on how the women's situation evolves to offer concrete indications and tools to policymakers so that they can 
operate effectively in single cultural, economic, social and political contexts. Understanding "how" requires a qualitative research approach with in-depth analyses of case studies to understand such a complex phenomenon. Accordingly, the papers of this book mean to offer a contribution to the theme of women in business from a micro perspective.

\section{Women in Business as Actors of Change and Innovation: A Micro Perspective}

The role of women in entrepreneurship, management and corporate governance is regarded as central to the development and welfare of economies. Since the early 1980s, there has been increased interest in women managers and entrepreneurs, often from an interdisciplinary approach combining, for example, sociology, psychology, management and organisational studies and economics. Nowadays, research on women in management and organisations is continuously and rapidly evolving (Paoloni and Demartini 2016). Research on the way women face new business challenges within organisations as entrepreneurs, owners and managers, as well as workers, can contribute to understanding the new drivers affecting value creation dynamics in our knowledge-based society. Accordingly, this book tries to offer some insights on how women create, process and share knowledge in their business activity through the application and exploitation of novel creative ideas and solutions.

Specifically, contributions will focus on the following topics:

- Female entrepreneurship challenges in the innovative sectors;

- Women's participation in the ownership, management and leadership of family business;

- Women's opportunities and difficulties in professional careers;

- Ideas and thoughts for overcoming gender inequalities.

The choice of the field of study that female students and male students make is perpetuating gender segregation in labour markets, with women underrepresented in the business sector and concentrated in the areas of health, well-being, education and administration. For this reason, it is interesting to analyse the challenges that women face when they enter advanced and extremely competitive sectors.

In this book, three articles deal with female entrepreneurs in high-tech and innovative sectors.

The first article by Paola Demartini is titled: Innovative Female-Led Startups. Do Women in Business Underperform? The spur of innovative startups has provided an unprecedented opportunity for female entrepreneurship. However, mainstream literature on startups has elaborated a gender performance gap hypothesis. Considering the speed of technological, social and cultural changes that have taken place in this millennium, the author wonders if this gap can still be found today, with particular reference to new technology-based ventures (Berger and Kuckertz 2016). The research results reveal that as far as financial performance is concerned, innovative female-led startups do not lag behind male ones in terms of dimension, company profitability, efficiency and financial management. However, findings confirmed that female businesses raise, on average, a lower amount of financial resources in comparison to men. To fully understand the value that female entrepreneurs can create, the author deems that future research should extend the assessment of female business performance outside the mainstream field and consider indicators referring to well-being and societal impact.

Indeed, a famous professional report (Startup Genome 2018) tackled the issue in its latest survey looking at how female and male founders might differ as far as their goals are concerned. Unsurprisingly, women are more likely to be oriented toward goals with a societal impact than men. In fact, they say they want to "change the world" with their startups, while men seem to be more market-oriented and more likely to say their primary mission is to "build high-quality products" (ib: 41).

The aim of the second paper "Female-Owned Innovative Startups in Italy: Status Quo and Implications" by Paola Paoloni and Giuseppe Modaffari is to provide an overview of the current literature on this business phenomenon with regard to gender studies and to point out what has happened in the Italian context. The absence of complex organisational structures in female startups is demonstrated by the results found in the literature which deals with the different problems encountered by the entrepreneur 
in doing business (Neill et al. 2015). By comparing the results that emerged in Paoloni-Demartini's study (2016) on female entrepreneurship, the authors have found the same difficulties common to the entrepreneur in starting their business. These concern, above all, the difficulty in facing the startup phase, the undercapitalisation of the company and the difficulties in accessing credit, the latter also confirmed by the empirical research carried out within the Italian economic context.

Therefore, from both papers, the suggestion to policymakers to support women entrepreneurs' access to credit emerges. This theme is relevant for all startups, but it is even more important for high-tech companies and particularly so for women who often suffer from the prejudice of not being in charge of business enterprises with performances similar to those of men.

The third paper by Katherina Kuschel, "Women Founders in the Technology Industry: The Startup Relatedness of the Decision to Become a Mother", explores the decision to become a mother among women in the technology industry, particularly if there is an "optimal context" regarding startup development. Findings suggest two sources of "mumpreneurs" in technology ventures: (1) women who created a startup while young and childless, postponing maternity until the business was "stable" and (2) mothers who created a technology venture as a strategy to gain higher levels of flexibility and autonomy than they experienced in the corporate world. The results of this work contribute to theory development by revealing the "startup-relatedness" of family decisions by women founders in the technology industry.

Hence, this research shows that competencies and skills that allow women to become successful entrepreneurs in the technologically advanced sectors do not guarantee equality. In fact, if childcare costs remain high, it will not be economically viable for women to work full time. Furthermore, as long as culture penalises women, who decide or are socially bound to take a break to have a child or assist elderly relatives, and as long as women continue to bear the brunt of unpaid domestic work, it will be difficult for them to realise their full potential in the labour market and in business.

This specific topic is addressed in the paper titled "It's Always a Women's Problem! Micro-Entrepreneurs, Work-Family Balance and Economic Crisis" by Francesca Maria Cesaroni, Maria Gabriella Pediconi and Annalisa Sentuti. Gender inequality in the division of family work is vastly corroborated and work-family balance is an important topic in the female entrepreneurship field of research. Even if work-family balance should be a necessity indiscriminately perceived by all women and men who have a paid job, it is a particularly pertinent issue for women, called to find an equilibrium between work and family. This study analyses the situation of men and women entrepreneurs in the Italian context in order to investigate how the economic crisis has affected the work-family balance. Findings show that the work-family balance of women entrepreneurs does not seem to have been particularly affected by the crisis. Difficulties in managing relations between firm and family are more structural, that is, mostly related to the person's family condition and the disparity of roles between men and women in the family context, than conjunctural. This result seems to suggest, mainly to policymakers who deal with gender equality and supporting policies of work-family balance, the opportunity to manage the question considering two aspects: gender culture and services to be offered to support the family.

Hence, the provision of services is a necessary but perhaps insufficient condition to support women entrepreneurs and female workers. A cultural change, which modifies the common way of thinking about the division of roles between men and women within the family, is also necessary.

The difficulties women face in career advancement is the topic addressed by three contributions. The issue of women's participation in top management and boardroom positions has received increasing attention in the academic literature and the press but, the pace of advancement for women managers and directors continues to be slow and uneven.

In the paper "Women Career Paths in Accounting Organisations: Big4 Scenario", Adriana Tiron-Tudor and Widad Atena Faragalla analyse the gender issues present in the accounting profession, and more precisely, on the career paths one could follow in the accounting profession. Findings reveal that the most disputed career path in the literature is working in a large auditing firm. In this context, gender 
discrimination is very much present through glass ceiling phenomena, double standard, motherhood and the aftermath that comes with it. Indeed, the findings show that motherhood is an important reason why women do not advance to partners as easily or as fast as men. The overall findings revealed that breaking through the ceiling and overcoming all the obstacles to reaching the top level, for women, is still difficult.

Strictly related to the latter issue is the paper "Women's Role in the Accounting Profession: A Comparative Study between Italy and Romania" by Mara Del Baldo, Adriana Tiron-Tudor and Widad Atena Faragalla. Historically, in most countries, the accounting profession has always been male-dominated. Liberal professions such as lawyers, engineers, architects and doctors share the common trait of conservatism. The accounting profession, which is also a liberal profession, is no exception. Starting from this premise, this work aims to provide, using a historical and institutional perspective, a picture of the past and current "journey" in the accountancy profession of women chartered accountants and auditors in Italy and Romania. Drawing from the theoretical framework of gendered construction of the accounting profession, the paper points out issues affecting the presence and degree of representativeness and the role of women within the National Chartered Association and their continued under-representation in Italy and Romania.

In this stream of research, Katherina Kuschel and Erica Salvaj present, in their paper titled "Opening the "Black Box". Factors Affecting Women's Journey to Top Management Positions: A Framework Applied to Chile", a framework of the factors that, at the individual, organisational and public policy level, affect both career persistence and the advancement of women in top management positions. In Chile, only 32 per cent of women "persist", or have a career without interruptions, mainly due to issues with work-family integration. Women who "advanced" in their professional careers represent 30 per cent of high management positions in the public sector and 18 per cent in the private sector. Only 3 per cent of general managers in Chile are women. Hence the authors draw business leaders' and public policymakers' attention to designing organisations that retain and promote talented women in top positions.

Two articles that offer insights for further developments and research studies bring this book to an end.

The first article, titled "Adoption of Gender-Responsive Budgeting (GRB) by an Italian Municipality" by Giovanna Galizzi, Gaia Viviana Bassani and Cristiana Cattaneo, offers insight to public officers on how an instrument can be a real help to overcome gender inequalities. Over the past few decades, many governments throughout the world have promoted gender-responsive budgeting (GRB). With its focus on equality, accountability, transparency and participation in the policy-making process, GRB shares some relevant principles with public governance principles. In detail, the case study shows that, when GRB is fully developed, the stakeholders involved are both internal and external, and these multiple actors, in pursuing gender equality, cooperate to achieve a shared, public aim. In this way, GRB gives effectiveness to the public decision-making process, contributing to greater incisiveness in the local government's management and creation of a gender-sensitive governance process.

Finally, the paper "Female Entrepreneurship in Perspective: A Methodological Issue" by Paola Paoloni and Gabriele Serafini proposes some questions for scholars. A methodological approach to the concept of female entrepreneurship has not yet been studied: Is female entrepreneurship an individual or collective concept? Is it considered a social or natural variable? The authors try to clear up these alternatives, which are preliminary questions for future research on female entrepreneurship. The term female relates to gender issues and collective characteristics but only when placed next to the term entrepreneurship, which is usually intended as an individual variable (Parker 2018, p. 300). However, the authors state that research on female entrepreneurship has not yet investigated whether it is an individual or collective variable and whether it has a social or natural derivation. Furthermore, inquiry on female entrepreneurship can be intended as a gender-based field of research, or research on the standardised qualities and functions of standardised human beings, rather than research on a particular function that characterises individuals. Hence, the originality of this research consists in its fourfold 
classification of the concept of female entrepreneurship, intended as a preparatory step to the analysis of its characteristics and measures.

Funding: This research received no external funding.

Conflicts of Interest: The author declares no conflict of interest.

\section{References}

Abu-Ghaida, Dina, and Stephan Klasen. 2004. The costs of missing the Millennium Development Goal on gender equity. World Development 32: 1075-107. [CrossRef]

Allendorf, Keera. 2007. Do Women's Land Rights Promote Empowerment and Child Health in Nepal? World Development 35: 1975-88. [CrossRef] [PubMed]

BarNir, Anat. 2012. Starting technologically innovative ventures: Reasons, human capital, and gender. Management Decision 50: 399-419. [CrossRef]

Beede, David N., Tiffany A. Julian, David Langdon, George McKittrick, Beethika Khan, and Mark E. Doms. 2011. Women in STEM: A gender gap to innovation. Economics and Statistics Administration Issue Brief.. [CrossRef]

Benería, Lourdes, Günseli Berik, and Maria Floro. 2015. Gender, Development and Globalization: Economics as If All People Mattered. Abingdon-on-Thames: Routledge.

Berger, Elisabeth S. C., and Andreas Kuckertz. 2016. Female entrepreneurship in startup ecosystems worldwide. Journal of Business Research 69: 5163-68. [CrossRef]

Bobbitt-Zeher, Donna. 2007. The gender income gap and the role of education. Sociology of Education 80: 1-22. [CrossRef]

Broadbridge, Adelina, and Birgit Weyer. 2007. Twenty years later: Explaining the persistence of the glass ceiling for women leaders. Women in Management Review 22: 482-96.

Cajaiba-Santana, Giovany. 2014. Social innovation: Moving the field forward. A conceptual framework. Technological Forecasting and Social Change 82: 42-51. [CrossRef]

Cornwall, Andrea, and Althea-Maria Rivas. 2015. From 'gender equality and 'women's empowerment'to global justice: Reclaiming a transformative agenda for gender and development. Third World Quarterly 36: 396-415. [CrossRef]

Cotter, David A., Joan M. Hermsen, Seth Ovadia, and Reeve Vanneman. 2001. The glass ceiling effect. Social Forces 80: 655-81. [CrossRef]

Duflo, Esther. 2012. Women empowerment and economic development. Journal of Economic Literature 50: 1051-79. [CrossRef]

Edler, Jakob, and Jan Fagerberg. 2017. Innovation policy: What, why, and how. Oxford Review of Economic Policy 33: 2-23. [CrossRef]

Fairlie, Robert W., and Alicia M. Robb. 2009. Gender differences in business performance: Evidence from the Characteristics of Business Owners survey. Small Business Economics 33: 375. [CrossRef]

Ferrant, Gaëlle. 2011. How Gender Inequalities Hinder Development: Cross-Country Evidence. HAL Id: halshs-00609828. Available online: https://halshs.archives-ouvertes.fr/halshs-00609828 (accessed on 23 July 2019).

Ferrant, Gaëlle, and Alexandre Kolev. 2016. Does Gender Discrimination in Social Institutions Matter for Long-Term Growth? Cross-Country Evidence. Working Paper No. 330. Paris: OECD Publishing, Available online: https://doi.org/10.1787/5jm2hz8dgls6-en (accessed on 23 July 2019).

Godin, Benoit. 2015. Innovation Contested: The Idea of Innovation over the Centuries. Abingdon-on-Thames: Routledge.

HDRO. 2018. Technical Notes. UN Development Programm. Available online: http://hdr.undp.org/sites/default/ files/hdr2018_technical_notes.pdf (accessed on 23 July 2019).

Henry, Colette, Lene Foss, and Helene Ahl. 2016. Gender and entrepreneurship research: A review of methodological approaches. International Small Business Journal 34: 217-41. [CrossRef]

Kabeer, Naila, and Luisa Natali. 2013. Gender Equality and Economic Growth: Is there a Win-Win? IDS Working Papers 2013: 1-58. [CrossRef]

King, Elizabeth, and Andrew Mason. 2001. Engendering Development: Through Gender Equality in Rights, Resources, and Voice. Washington, DC: The World Bank. 
Klasen, Stephan. 2002. Low schooling for girls, slower growth for all? Cross-country evidence on the effect of gender inequality in education on economic development. The World Bank Economic Review 16: 345-73. [CrossRef]

Klasen, Stephan, and Francesca Lamanna. 2009. The impact of gender inequality in education and employment on economic growth: New evidence for a panel of countries. Feminist Economics 15: 91-132. [CrossRef]

Neill, Stern, Lynn Metcalf, and Jonathan L. York. 2015. Seeing what others miss: A study of women entrepreneurs in high-growth startups. Entrepreneurship Research Journal 5: 293-322. [CrossRef]

OECD Development Centre. 2014. SIGI Methodological Background Paper. Available online: https://www.oecd. org/dev/development-gender/Backgroundpaper_cover.pdf (accessed on 23 July 2019).

Paoloni, Paola, and Paola Demartini. 2016. Women in management: Perspectives on a decade of research (2005-2015). Palgrave Communications 2: 16094. [CrossRef]

Parker, Simon C. 2018. The Economics of Entrepreneurship. Cambridge: Cambridge University Press.

Phills, James A., Kriss Deiglmeier, and Dale T. Miller. 2008. Rediscovering social innovation. Stanford Social Innovation Review 6: 34-43.

Roushdy, Rania. 2004. Intrahousehold Resource Allocation in Egypt: Does Women's Empowerment Lead to Greater Investments in Children? Paper presented at Economic Research Forum. Available online: https://erf.org.eg/wp-content/uploads/2017/04/0410_final.pdf (accessed on 23 July 2019).

Rubalcava, Luis, Graciela Teruel, and Duncan Thomas. 2009. Investments, Time Preferences, and Public Transfers Paid to Women. Economic Development and Cultural Change 57: 507-38. [CrossRef]

Schady, Norbert, and José Rosero. 2008. Are Cash Transfers Made to Women Spent Like Other Sources of Income? Economics Letters 101: 246-48. [CrossRef]

Startup Genome. 2018. Global Startup Ecosystem Report 2018. Available online: https://startupgenome.com/ reports/2018/GSER-2018-v1.1.pdf (accessed on 15 August 2019).

United Nations. 2015. Transforming our World: The 2030 Agenda for Sustainable Development. Available online: https://sustainabledevelopment.un.org (accessed on 23 July 2019).

United Nations. 2018. Gender Equality: Why It Matters. Available online: https://www.un.org/ sustainabledevelopment/wp-content/uploads/2018/09/Goal-5.pdf (accessed on 23 July 2019).

UN Women. 2017. SDG 5: Achieve Gender Equality and Empower All Women and Girls. Available online: https://www.unwomen.org/en/news/in-focus/women-and-the-sdgs/sdg-5-gender-equality (accessed on 23 July 2019).

van der Have, Robert P., and Luis Rubalcaba. 2016. Social innovation research: An emerging area of innovation studies? Research Policy 45: 1923-35. [CrossRef]

WorldBank. 2001. Engendering Development through Gender Inequality in Rights, Resources and Voice. Washington, DC: World Bank.

(C) 2019 by the author. Licensee MDPI, Basel, Switzerland. This article is an open access article distributed under the terms and conditions of the Creative Commons Attribution (CC BY) license (http://creativecommons.org/licenses/by/4.0/). 